U. S. Department of the Interior

U. S. Geological Survey

\title{
Volcanic-Hazard Zonation for Mount St. Helens, Washington, 1995
}



by

Edward W. Wolfe and Thomas C. Pierson

U.S. Geological Survey

Cascades Volcano Observatory

5400 MacArthur Blvd.

Vancouver, WA 98661

\section{Open-File Report 95-497}

This report is preliminary and has not been reviewed for conformity with U.S. Geological Survey editorial standards or with the North American Stratigraphic Code. Any use of trade, firm, or product names is for descriptive purposes only and does not imply endorsement by the U.S. Government. 
CONTENTS

Introduction . . . . . . . . . . . . . . . . . . . . . . . . . . . . . . . . 1

Hazardous Geologic Processes . . . . . . . . . . . . . . . . . . . . . . . . . 2

Tephra fall . . . . . . . . . . . . . . . . . . . . . . . . . . . . 2

Pyroclastic flows . . . . . . . . . . . . . . . . . . . . . . . . . . . . . 3

Pyroclastic surges . . . . . . . . . . . . . . . . . . . . . . . . . . . . . . 4

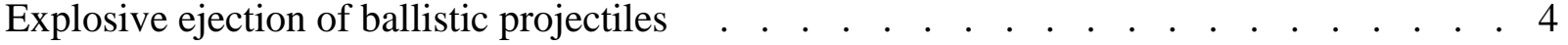

Lateral blasts . . . . . . . . . . . . . . . . . . . . . . . . . . 4

Lava flows . . . . . . . . . . . . . . . . . . . . 5

Lahars . . . . . . . . . . . . . . . . . 5

Hazard zonation . . . . . . . . . . . . . . . . . . . . . . . . . . . . . . . 6

Tephra-fall hazard . . . . . . . . . . . . . . . . . . . . . . . . . . . . . 6

Flowage hazard . . . . . . . . . . . . . . . . . . . . . . . . . . . . . . 7

Flowage-hazard zone 1 . . . . . . . . . . . . . . . . . . . . . . . . . . . . 8

Flowage-hazard zone 2 . . . . . . . . . . . . . . . . . . . . . . . . . . . . . . . . . . 9

Flowage-hazard zone 3 . . . . . . . . . . . . . . . . . . . . . . . . . . . . . . . . . 9

Potential water sources for lahars at Mount St. Helens ～. . . . . . . . . . . . . . 9

Effect of the SRS sediment dam _ . . . . . . . . . . . . . . . . . . . . . . 10

Monitoring and warnings . . . . . . . . . . . . . . . . . . . . . . . . . . 11

References cited and suggested reading . . . . . . . . . . . . . . . . . . 12

\section{ILLUSTRATIONS}

Plate 1. Flowage-hazard zonation map . . . . . . . . . . . . . . . In pocket

Figure 1. Eruptive history of Mount St. Helens shown on a logarithmic time scale . . . . . 2

2. Map of Washington and Oregon showing the percentage probability of accumulation of ten or more centimeters of tephra from a large eruption of Mount St. Helens . . . . . . . . . . . . . . . . . . . . . . . . . 7

3. Annual probability of accumulation of ten or more centimeters of tephra in Washington and Oregon from eruptions throughout the Cascade Range . . . . .8

4. Volume of ice and snow in the Mount St. Helens crater . . . . . . . . . . . . 9

\section{TABLES}

1. Expected travel times for lahars triggered by a large eruption of Mount St. Helens . . . . 6

Cover photo: May 18, 1980 eruption of Mount St. Helens. Austin Post, U.S. Geological Survey 


\title{
Volcanic-Hazard Zonation for Mount St. Helens, Washington, 1995
}

\author{
by
}

Edward W. Wolfe and Thomas C. Pierson

\section{INTRODUCTION}

Mount St. Helens remains a potentially active and dangerous volcano, even though it is now (1995) quiescent. In the last 515 years, it is known to have produced 4 major explosive eruptions (each with at least $1 \mathrm{~km}^{3}$ of eruption deposits, fig. 1) and dozens of lesser eruptions. Two of the major eruptions were separated by only 2 years. One of those, in 1480 A.D., was about 5 times larger than the May 18, 1980 eruption, and even larger eruptions are known to have occurred during Mount St. Helens' brief but very active 50,000-yr lifetime. Following the most recent major eruption, on May 18, 1980, there were 5 smaller explosive eruptions over a period of 5 months. Thereafter, a series of 16 dome-building eruptions through October 1986 constructed the new, 270-m(880-ft-) high, lava dome in the crater formed by the May 18, 1980 eruption.

Volcanoes commonly repeat their past behavior. Thus, it is likely that the types, frequencies, and magnitudes of past activity will be repeated in the future. Among the possibilities for renewed eruptive activity at Mount St. Helens are resumption of dome growth, eruption of basaltic or andesitic tephra and lava flows, or explosive eruptions of dacitic tephra and pyroclastic flows in volumes that could be as large as or even larger than the volume erupted in 1980. Lahars (sediment-rich floods in volcanic terrain) generated by snowmelt are likely to accompany any eruptive activity. Lahars may also be generated without an eruption by intense storm runoff over erodible sediment, landslides, or by failure of the Castle Lake impoundment as a consequence of an earthquake or heavy rains. Neither a large debris avalanche nor a major lateral blast like those of May 18, 1980 is likely now that a deep, open crater has formed.

Sufficient time has elapsed since the last dome-building eruption in October 1986 for magma in the conduit beneath the dome to crystallize and form a plug. The pressure needed to overcome this blockage may exceed that of any eruption since May 18, 1980; therefore, the next eruption may be initially explosive owing simply to blockage of the conduit. Several scenarios for renewed eruptive activity notwithstanding, a conservative approach to hazards assessment requires us to assume, until there is specific evidence to the contrary, that the next eruption will be explosive and as large as or larger than the eruption of May 18, 1980.

Basalt-Dark, low-silica (less than 53 percent $\mathrm{SiO}_{2}$ ) volcanic rock that is relatively fluid when molten; eruptions of basalt are generally nonexplosive and tend to produce relatively long thin lava flows like those common in Hawaii.

Dacite - Light-colored, fairly silica-rich (63 to 68 percent $\mathrm{SiO}_{2}$ ) volcanic rock that is viscous when molten; eruptions are commonly explosive (e.g., Mount St. Helens' eruption of May 18, 1980) and may produce voluminous tephra, pyroclastic flows, and lava domes.

Andesite-Volcanic rock intermediate in color, composition, and eruptive character between basalt and dacite. 


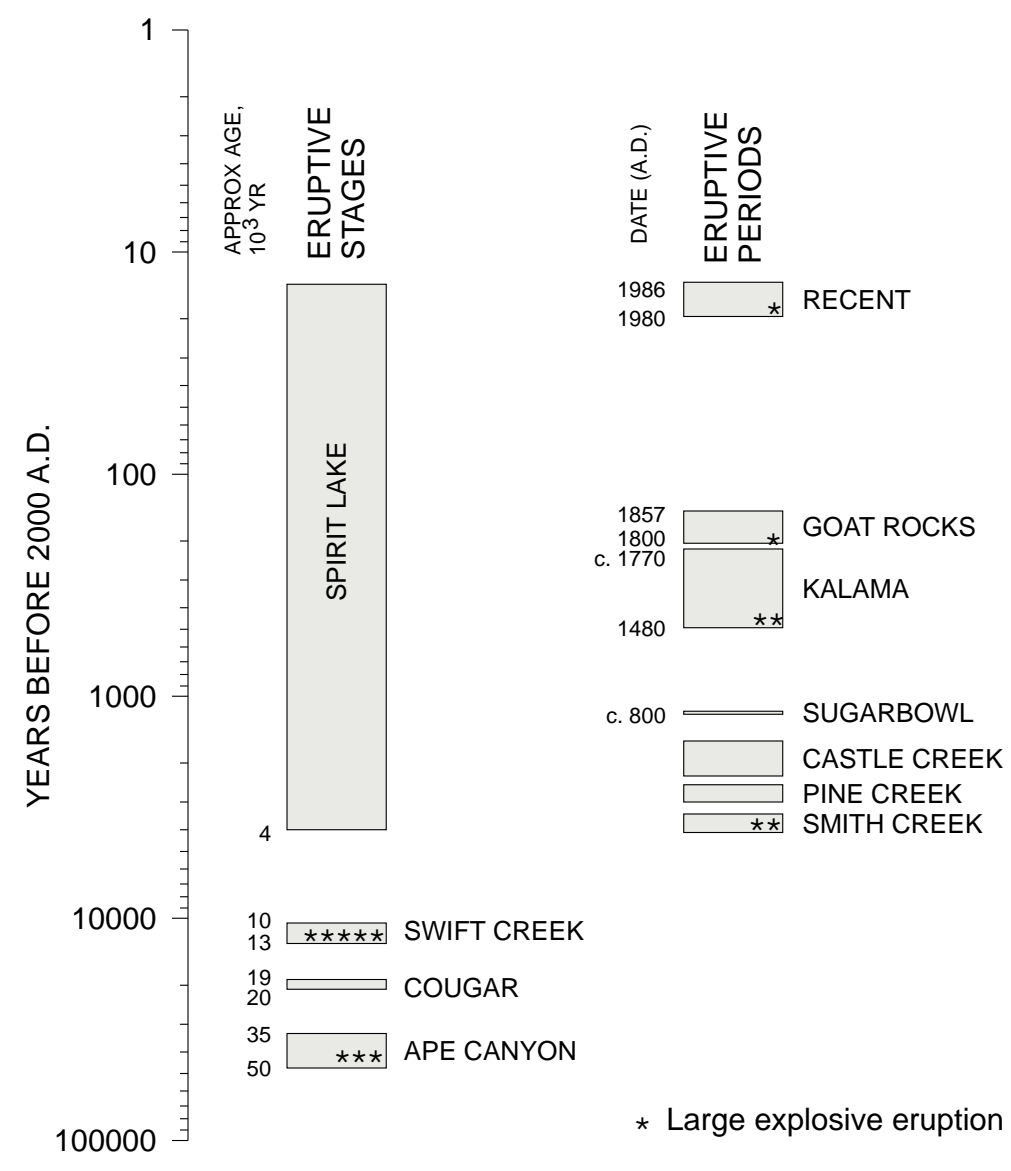

Figure 1. Eruptive history of Mount St. Helens shown on a logarithmic time scale (expands with decreasing age). Eruptive periods (at right) are subdivisions of the Spirit Lake eruptive stage. Large explosive eruptions are those that deposited at least $25 \mathrm{~cm}$ of tephra at distances of 8 to $10 \mathrm{~km}$ downwind of Mount St. Helens. Modified from Pallister and others (1992). Additional data from Mullineaux (in press) and Yamaguchi and Hoblitt (in press).

Future eruptions are certain. Although we do not know when the next one will occur, it should be planned for. This report delineates areas that are likely to be at risk (hazard zones) during another major eruption. It updates previous assessments, taking into account both recent experience at erupting volcanoes and topographic, hydrologic, and geologic changes initiated at Mount St. Helens by the 1980 eruptions. These changes include (1) beheading of the summit, forming a truncated cone with a deep crater open to the north, (2) a large and growing volume of snow and ice in the crater, (3) the existence of a large, potentially unstable, debris-dammed lake (Castle Lake) in a tributary to the North Fork Toutle River, and (4) large volumes of erodible sediment in most of the river valleys draining the volcano.

\section{HAZARDOUS GEOLOGIC PROCESSES}

This section describes the major hazardous geologic processes that are likely to occur in the future at Mount St. Helens. Any or all may occur as consequences of future eruptions. However, one potentially lethal process (lahars) can also be triggered by noneruptive mechanisms and thus may occur with little warning. We do not address other noneruptive processes such as rockfalls, avalanches, and small debris flows that commonly produce local hazards in areas of steep terrain, both volcanic and nonvolcanic.

\section{Tephra Fall}

During explosive eruptions, a mixture of hot volcanic gas and tephra, which includes volcanic ash (sand-sized or finer particles of volcanic rock) and larger fragments, is ejected rapidly into the air from volcanic vents. This plume of rock fragments and expanding gas not only jets upward but is commonly less dense than the air and thus rises into the atmosphere until no longer buoyant. (The May 18, 1980 tephra plume rose about $25 \mathrm{~km}$ [15 mi] in less than $30 \mathrm{~min}$ ). As the energy required to keep them in suspension diminishes, the particles begin to fall out of the plume under the influence of gravity. Large fragments fall back to earth close to the vent. Finer (ash-size) particles drift downwind as a large 
cloud, eventually falling to the ground to form a blanket-like ash deposit that is generally thinner and finer-grained with increasing distance away from the vent. Large eruptions can produce tephra thicknesses of many meters (yards) near the vent, with tephra fragments ranging up to tens of centimeters (10-20 inches) in diameter, whereas tephra deposits several hundred kilometers (several hundred miles) downwind typically consist of a trace to a few centimeters (few inches) of fine powder.

The major hazards of tephra fall are derived from (1) impact of falling fragments, (2) suspension of abrasive fine particles in the air and water, and (3) burial of structures, transportation routes, and vegetation. As learned in the 1980 eruptions of Mount St. Helens, tephra fall can cause severe social disruption over a vast area.

Fragments larger than a few centimeters (1-2 in), that have sufficient mass to cause severe injury or damage through impact, generally fall within about $10 \mathrm{~km}(6 \mathrm{mi})$ of the vent. Thus, damaging or lethal impact from falling tephra is likely only in the immediate vicinity of Mount St. Helens.

Ash suspended in the air from a large eruption can be a major source of aggravation and hazard even hundreds of kilometers (a few hundred miles) downwind from its source, both during its initial accumulation and later as fine dry ash is remobilized by wind or passing vehicles. Airborne ash (a) causes eye and respiratory irritation for some people and can cause severe air-quality problems at critical facilities such as hospitals; (b) can cause severe visibility reduction, even complete darkness during daylight hours, which can make driving particularly hazardous; (c) can damage unprotected machinery, especially internal-combustion engines; (d) can cause short circuits in electric-power transmission lines; and (e) can endanger aircraft flying through ash clouds, especially jet aircraft, which can completely lose engine power. Suspension of ash in water can lead to damage at hydroelectric facilities, irrigation pumping stations, sewage-treatment facilities, and stormwater systems.

Burial by tephra can collapse roofs of buildings and other structures, break power and telephone lines, and damage or kill vegetation. Wet tephra is 2 to 3 times heavier than dry uncompacted tephra and adheres better to sloping surfaces. Ten centimeters (4 inches) of wet tephra impose a load in the range of 100 to $125 \mathrm{~kg} / \mathrm{m} 2$ (approximately 20 to $25 \mathrm{lb} / \mathrm{ft} 2$ ), sufficient to cause some roofs to collapse.

\section{Pyroclastic Flows}

Pyroclastic flows are avalanches of hot (300 $\left.800^{\circ} \mathrm{C}\left[570-1470^{\circ} \mathrm{F}\right]\right)$, dry, volcanic rock fragments and gases that descend a volcano's flanks at speeds ranging from 10 to more than 100 meters per second (20 to more than 200 miles per hour). Owing to their mass, high temperature, high speed, and great mobility, pyroclastic flows are destructive and pose lethal hazard from incineration, asphyxiation, burial, and impact. Because of their high speed, pyroclastic flows are difficult or impossible to escape. Evacuation must take place before such events occur.

Just as mixtures of hot volcanic gas and tephra rise into the atmosphere when the mixture is less dense than the surrounding air, mixtures of hot volcanic rock fragments and gas that are more dense than the surrounding atmosphere flow down the volcano flanks as pyroclastic flows. Such flows can originate from high vertical eruption columns, from low fountains of erupting pyroclastic material that appear to "boil over" from the vent, and from gravitational or explosive disruption of hot lava domes. The first two mechanisms operated during the explosive eruptions of 1980 at Mount St. Helens and are likely again should eruptive activity be resumed. The third mechanism, disruption of a hot lava dome, has operated at numerous times in the past at Mount St. Helens but would be significant there only if new dome growth should become established.

Driven by gravity, pyroclastic flows seek topographically low areas and, beyond the steep flanks of the volcano, tend to be channeled into valleys. Pyroclastic flows from the May 18, 1980 eruption ran out only about $8 \mathrm{~km}(5 \mathrm{mi})$ from the vent. As they impinged on Johnston Ridge, they were deflected westward downvalley and eastward to Spirit Lake. During the past 4,000 years, during which time the volcano's modern edifice formed, numerous pyroclastic flows are known to have traveled at least as far as $10-15 \mathrm{~km}(6-9 \mathrm{mi})$, and at 
least one older flow is known to have traveled as much as $20 \mathrm{~km}(12 \mathrm{mi})$. Although the present crater geometry favors distribution of pyroclastic flows into the North Fork Toutle River valley, all flanks of the volcano are subject to pyroclastic-flow hazard during a large eruption.

\section{Pyroclastic Surges}

Pyroclastic surges are turbulent, relatively low-density (but still denser than air), mixtures of gas and rock that flow above the ground surface at high velocities similar to those of pyroclastic flows. Hot pyroclastic surges are generated similarly to pyroclastic flows as well as by lateral blasts and as mobile, turbulent ash clouds winnowed from pyroclastic flows. Hazards resulting from pyroclastic surges include incineration, destruction by high-velocity ash-laden winds, impact by rock fragments, burial by surge deposits, exposure to noxious gases, and asphyxiation. Like pyroclastic flows, pyroclastic surges are too fast-moving to escape; evacuation must take place before they occur.

Because they are less dense, pyroclastic surges are less constrained by topography than are pyroclastic flows. Surges may climb or surmount valley walls, affecting areas well beyond the limits of pyroclastic flows. For example, pyroclastic surges surmounted Johnston Ridge and entered the drainage of South Coldwater Creek on May 18, 1980, even though the related pyroclastic flows were deflected by the steep north-facing escarpment of the ridge.

The presence of water-saturated sediment beneath the crater floor raises the potential for steam-driven explosions that could be generated by intrusion of magma into the water-bearing material. Such explosions may produce relatively low-temperature pyroclastic surges that could flow at high speeds through the crater breach and down the volcano's north flank toward Spirit Lake and Johnston Ridge. Steam-driven explosions are likely during early stages of the next eruption.

\section{Explosive Ejection of Ballistic Projectiles}

Volcanic explosions can impel rock fragments on ballistic trajectories that may be counter or oblique to the wind direction. Such events may occur either during or independently from an ongoing magmatic eruption and are likely to occur without warning. A blast related to emplacement of the Sugarbowl dome on the north flank of Mount St. Helens about 1,200 years ago propelled ballistic fragments as large as $5 \mathrm{~cm}(2 \mathrm{in})$ as far as $10 \mathrm{~km}(6$ mi) from the vent. More recently, a series of relatively small steam-driven explosions in 1989-91 threw hundreds of blocks, some as large as a meter (yard), for distances of as much as $1 \mathrm{~km}(0.6 \mathrm{mi})$ from the dome within the Mount St. Helens crater. Similar explosions could occur without warning in the future but become progressively less likely with continued cooling of the dome's hot interior and the subsurface conduit that supplied the magma for dome growth.

\section{Lateral Blasts}

A lateral blast is a volcanic explosion that has a significant low-angle component and is principally directed toward a sector of no more than $180^{\circ}$. Lateral blasts may generate complex pyroclastic flows and surges and launch ballistic projectiles. Previous lateral blasts are known in two contexts at Mount St. Helens: (1) blasts generated by abrupt landslide-induced decompression of a shallow magma body and the hydrothermal system surrounding it within a volcano; (2) explosions originating from sudden release of gases at growing lava domes.

A massive landslide abruptly removed the volcano's summit on May 18, 1980, and the resulting decompression of shallow magma and the hydrothermal system that enveloped it initiated the well-known, highly destructive lateral blast. The current shape of the volcano-with its large crater and much lower summit makes a similar landslide and massive laterally directed blast unlikely when eruptive activity next resumes.

However, smaller lateral blasts could ensue if dome growth recurs. Explosions related to emplacement of the Sugarbowl dome about 1,200 years ago generated pyroclastic flows that extended several kilometers (miles) and impelled rock fragments at least $10 \mathrm{~km}(6 \mathrm{mi})$ from the vent. Destructive effects of a lateral blast that might occur from a new dome growing within the crater would 
be directed northward. Addition of a 50 percent safety factor to the $10-\mathrm{km}$ (6-mi) range identified for ballistic fragments from the Sugarbowl blasts suggests that hazard from rock projectiles might extend $15 \mathrm{~km}(9 \mathrm{mi})$ northward from the crater in laterally directed explosions from a growing dome. A comparable laterally directed explosion could result from abrupt failure of the plug blocking the 1980-86 conduit under elevated pressure related to renewed magmatic activity.

\section{Lava Flows}

Numerous elongate lava flows have issued from Mount St. Helens. Most have affected only areas within $10 \mathrm{~km}(6 \mathrm{mi})$ of the summit, but two basalt flows that issued about 1,700 years ago extended $16-17 \mathrm{~km}$ (c. $10 \mathrm{mi}$ ) from the volcano's summit; one of them, which flowed south to the Lewis River valley east of Cougar, contains the Ape Cave lava tube. Andesite lava flows, which were erupted repeatedly during the 16th century and once again at the beginning of the 19th century, were less fluid than the basalt and extended only as far as $6 \mathrm{~km}$ (4 mi) from the volcano's summit.

Lava flows are controlled by the topography; they flow downhill, becoming channeled into river valleys if they extend far enough. Thus, a lava flow affects only terrain that is downslope from its vent, which could be either in the crater or anywhere on the volcano's flanks. A lava flow from a vent in the present crater would be directed down the north flank of Mount St. Helens and possibly into the upper part of the North Fork Toutle River valley. Lava flows are destructive but generally not life-threatening because they normally advance so slowly that people can walk or run away from them.

Extremely viscous dacitic lava does not flow easily; it tends to form steep-sided lava domes over vents or very thick, stubby lava flows extending away from vents. On steep slopes like those of a volcano's upper flanks, the steep margins of such domes or stubby lava flows may collapse, spawning avalanches of hot volcanic debris that generate pyroclastic flows and surges. Such events have occurred repeatedly in the past at Mount St. Helens and would be expected again if a dome grows on the upper flanks or fills the crater.

\section{Lahars}

Lahars are rapidly flowing mixtures of water and rock debris (at sediment concentrations higher than for normal floods or stream flow) that originate from volcanoes. They can range from dense, viscous slurries resembling wet concrete and termed "debris flows" or "mudflows" (containing about two thirds sediment and one third water by volume) to turbulent muddy floods that carry relatively little sediment. Lahars can begin as sudden releases of large volumes of water or as large landslides of saturated soil and rock debris. Potential sources of large volumes of water include runoff from extremely heavy rainfall, rapid melting of snow and ice, and outbreaks of water from lakes. All of these mechanisms have produced lahars at Mount St. Helens in the past.

Lahars are gravity-controlled flows that are channeled into valleys as they move downhill, and they can flow about twice as fast as water in channels of similar depth and slope. Lahars triggered at Mount St. Helens in 1980 were 3 to 15 m (10 to 50 $\mathrm{ft}$ ) deep and traveled at speeds of 20 to $40 \mathrm{~m} / \mathrm{s}$ (45 to $90 \mathrm{mph}$ ) on the volcano's steep flanks; in valleys more than about $10 \mathrm{~km}$ ( 6 miles) from the volcano, they flowed typically at 10 to $20 \mathrm{~m} / \mathrm{s}$ ( 22 to $45 \mathrm{mph}$ ). In addition, lahars can get bigger as they move downstream by incorporating additional sediment and water en route (called bulking), commonly increasing in volume by a factor of 3 to 5. As lahars get farther from a volcano, they slow down and spread out in the wider, flatter river valleys, often burying roads, bridges, and buildings with their deposits. Past lahars at Mount St. Helens have traveled from 50 to $100 \mathrm{~km}$ (30 to 60 miles), often reaching the Columbia River via the Toutle, Kalama or Lewis Rivers.

Lahars threaten lives and property, both on the flanks of volcanoes and far downstream in the valleys that drain volcanoes. Lahars are a greater threat to life and property in communities of the Cowlitz and lower Toutle River drainages than any other volcanic phenomenon. Damage is done by impact from large boulders or logs carried in the flows, by high drag and buoyancy forces imposed by the dense fluid, by abrasion, and by burial. Lahars commonly destroy mature forests and any human-made structures in their paths, including bridges, dams, roads, pipelines, and buildings. They 
can also bury extensive areas of agricultural land, fill stream channels (decreasing a channel's capacity to safely carry normal high runoff), and block shipping lanes in navigable river channels. In contrast to pyroclastic flows and surges, lahars have sharply defined upper limits in well-defined valleys, and in many cases people can quickly climb or drive to safety by evacuating the valley floor. Future lahars at Mount St. Helens can be expected to have travel times approximately as shown in Table 1.

\section{HAZARD ZONATION}

\section{Tephra-fall Hazard}

A large eruption of Mount St. Helens can be expected to inject tephra to altitudes of $20-30 \mathrm{~km}$ (12-20 mi) and to deposit tephra over an area of
$100,000 \mathrm{~km}^{2}\left(40,000 \mathrm{mi}^{2}\right)$ or more. Wind direction and velocity, along with the vigor and duration of the eruption, control the location, size, and shape of the area affected by tephra fall. Wind direction and velocity vary with both time and altitude, making it impossible to predict the velocity and direction of tephra transport more than a few hours in advance. Westerly winds prevail; thus, significant tephra accumulation from a single eruption is more likely east than west of Mount St. Helens (fig. 2). The calculated probability that ten or more centimeters (four or more inches) of tephra from a large eruption will fall as far as $60 \mathrm{~km}$ (40 mi) directly east of Mount St. Helens is 20 percent; the probability that such an eruption would deposit ten or more centimeters (four or more inches) $60 \mathrm{~km}$ (40 mi) directly west of Mount St. Helens is less, between 1 and 2 percent.

Mount St. Helens has repeatedly produced voluminous tephra and has erupted much more frequently in recent geologic time than any other

Table 1. Expected travel times for lahars triggered by a large eruption of Mount St. Helens.

[Slower travel along the North Fork Toutle River reflects the greater width and lower gradient than in the steep, narrow channels on the west and south sides of the volcano. NFT = North Fork Toutle River, estimate based on computer simulation (Laenen and Orzol, 1987 [unadjusted flood peak]); SFT, P, M, K = South Fork Toutle River, Pine Creek, Muddy River, and Kalama River, estimate based on behavior of Mount St. Helens lahars on May 18, 1980. Lahars will not necessarily travel the full distance indicated by the table; Pine Creek and Muddy River lahars will terminate in Swift Reservoir.]

Distance (via river channels) from Mount St. Helens, $\mathrm{km}$ (mi)

$\begin{array}{rrrr} & & \text { NFT } & \text { SFT, P, M, K } \\ 10 & (6.2) & \mathbf{0 : 3 7} & \mathbf{0 : 1 1} \\ 20 & (12.4) & \mathbf{1 : 0 8} & \mathbf{0 : 3 0} \\ 30 & (18.6) & \mathbf{1 : 3 7} & \mathbf{0 : 5 4} \\ 40 & (24.9) & \mathbf{2 : 1 6} & \mathbf{1 : 2 1} \\ 50 & (31.1) & \mathbf{2 : 5 3} & \mathbf{1 : 4 9} \\ 60 & (37.3) & \mathbf{3 : 2 7} & \mathbf{2 : 2 0} \\ 70 & (43.5) & \mathbf{3 : 4 8} & \mathbf{2 : 5 3} \\ 80 & (49.7) & \mathbf{4 : 4 3} & \mathbf{3 : 3 1} \\ 90 & (55.9) & \mathbf{6 : 3 6} & \mathbf{4 : 1 8} \\ 100 & (62.1) & \mathbf{8 : 5 0} & \mathbf{5 : 1 2}\end{array}$

Estimated travel time, hr:min
NFT 


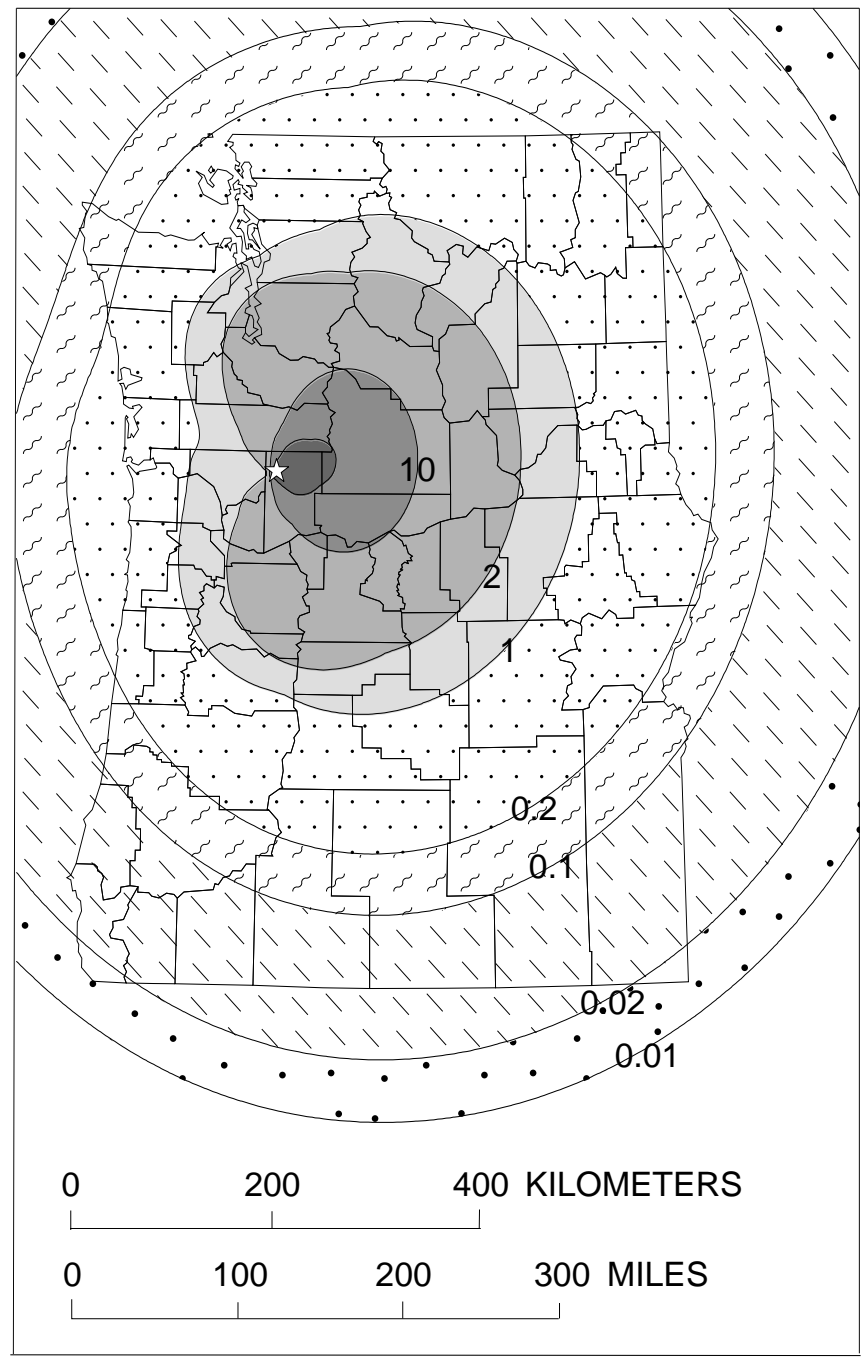

PROBABILITY

(PERCENT)

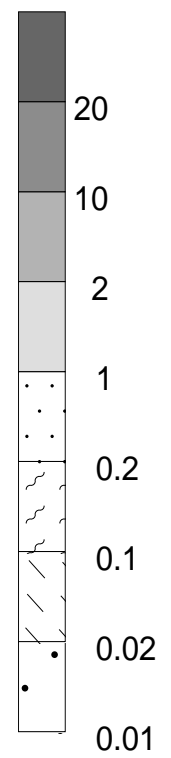

volcano in the Cascade Range. Thus, its influence dominates the annual-probability distribution in Washington and Oregon of ten or more centimeters (four or more inches) of tephra accumulation from eruptions throughout the Cascade Range (fig. 3).

\section{Flowage Hazard}

The accompanying flowage-hazard zonation map shows areas potentially threatened by flowage hazards from an eruption as large as any since 1480 A.D., from intense posteruption rainfall, or from an outbreak of Castle Lake. The map draws extensively on previously published hazard zonations (Crandell and Mullineaux, 1978; Miller, Mullineaux, and Crandell, 1981), which were strongly based on the geologic record of past eruptive events at Mount St. Helens. In addition, the current zonation reflects both changes in the landscape as a consequence of the 1980-86 eruptions and experience with recent volcanic eruptions at Mount St. Helens and elsewhere.

The flowage-hazard zonation map portrays three zones: (1) a proximal zone of high-concentration (high-density) flows, which are strongly channeled into topographically low areas; (2) a proximal zone of low-concentration (low-density) flows (pyroclastic surges), which are appreciably less constrained by topography; and (3) a distal zone, where well-channelized lahars represent the only significant flowage hazard. The proximal zones (1 and 2) are subject to the full gamut of 


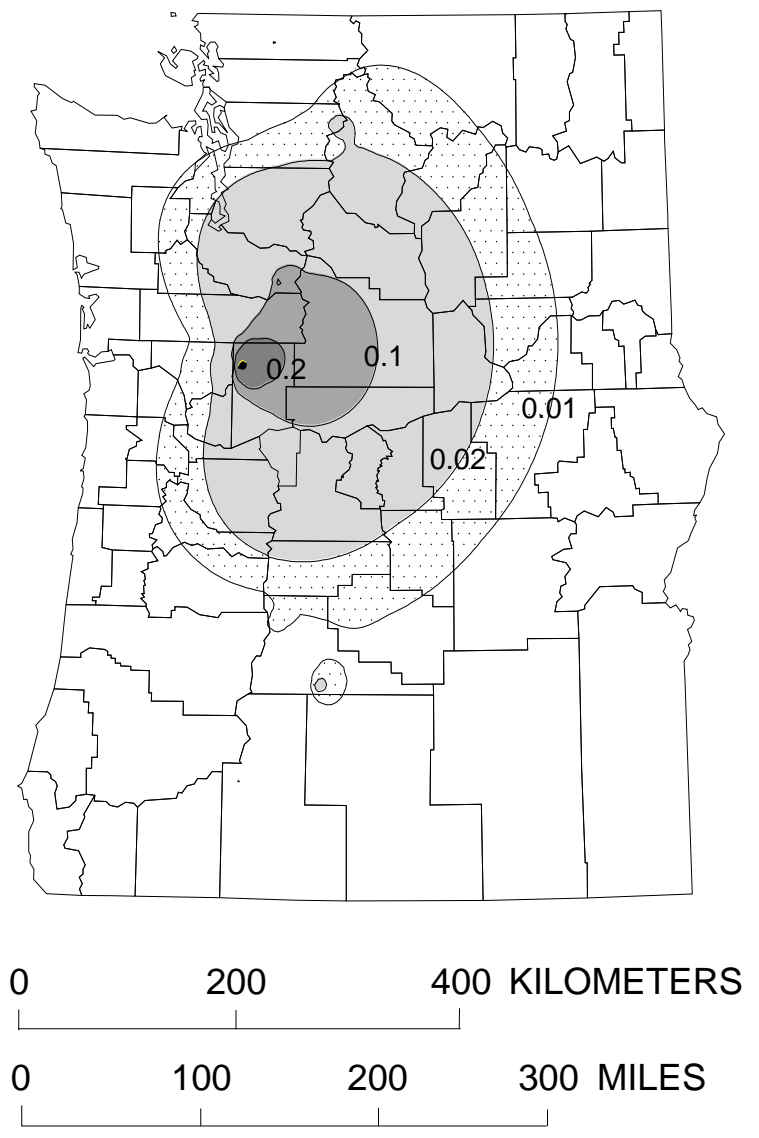

hazards-pyroclastic flows and surges, explosive ejection of rock fragments, laterally directed blasts, lava flows, and lahars. Most of the eruptive processes within the zones 1 and 2 occur so rapidly that it is too late to evacuate after an eruption has begun; in these areas, evacuation must occur before the eruption begins.

As shown in 1980, a single eruption is unlikely to affect the entire zoned area, but evidence before an eruption will probably be insufficient to identify which parts will be spared. Further, it is important to understand that hazard-zone boundaries are approximate. They indicate the most likely maximum extents of flows, based on past eruptive behavior or on results of numerical models, and they assume the next eruption will be explosive and as large or larger than the May 18, 1980 eruption. The actual extents of future flows will depend upon factors such as volume, mobility, velocity, and

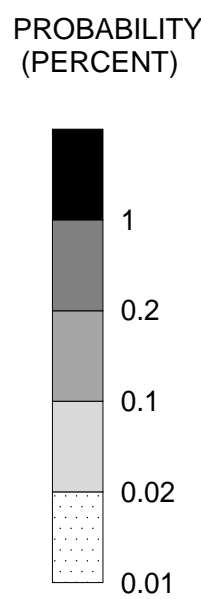

Figure 3. Annual probability of accumulation of ten or more centimeters (four or more inches) of tephra in Washington and Oregon from eruptions throughout the Cascade Range. Probability distribution reflects the frequency of explosive eruptions at each major Cascade volcano, the variability in the thickness of tephra that could be deposited at various downwind distances, and the variability in wind direction. exact mixture composition, all of which are difficult to forecast. Therefore, one must not assume that hazard-zone boundaries mark well-defined limits beyond which there is little or no risk of harm.

\section{Flowage-Hazard Zone 1}

Zone 1 represents the area vulnerable to passage of high-concentration (high-density) flows, including pyroclastic flows, lava flows, and the proximal parts of lahars. Such flows can spread across broad sectors of the volcano's upper slopes, but they become well channelized in the major drainages at lower elevations. The boundaries are similar to those shown by Miller and others (1981) after the 1980 eruptions, and they are based on field evidence for the distribution of past flows at Mount St. Helens and other volcanoes. 


\section{Flowage-Hazard Zone 2}

Zone 2 represents the area that could be overrun by pyroclastic surges, which are low-concentration (low-density) flows that are much less constrained by topography than are the high-concentration flows. Crandell and Mullineaux (1978) showed a similar but slightly less extensive zone for ash clouds (surges) associated with pyroclastic flows, based on their knowledge of the distribution of ash-cloud deposits in Mount St. Helens' geologic record. We expand the zone slightly on the basis of experience with highly mobile pyroclastic surges that leave thin deposits unlikely to be preserved in the geologic record. For example, a dilute surge at Redoubt Volcano, Alaska, in February 1990 deposited only a few millimeters of ash and small pebbles, fragments of transported, charred wood, and a scorched and battered bird carcass on a ridge crest $10 \mathrm{~km}(6 \mathrm{mi})$ distant and $700 \mathrm{~m}(2,300 \mathrm{ft})$ above the intervening valley bottom. The drop in elevation from the vent to the ridge crest was only $1,300 \mathrm{~m}(4,300 \mathrm{ft})$; a similarly mobile surge, if generated from an eruption column onto the south flank of Mount St. Helens, would probably have reached Swift Reservoir.

\section{Flowage-Hazard Zone 3}

Zone 3 includes the intermediate and lower reaches of valleys that could be inundated by lahars. The maximum size of a potential lahar is limited principally by the amount of available water, which can be estimated for the North Fork Toutle River (see below). However, several major uncertainties are involved in estimating potential lahar size. The zone- 3 hazard boundaries in the North Fork Toutle, main stem Toutle, and Cowlitz Rivers are based on previous numerical modeling studies for a hypothetical outbreak of Castle Lake (Laenen and Orzol, 1987; MacArthur and others, 1990), taking into account the effects of the U.S. Army Corps of Engineers' Sediment Retention Structure (SRS) on a lahar coming down the valley. If an outbreak of Castle Lake were to occur during a large storm or during an eruption that released water from the crater, a flood larger than that indicated by the zone-3 boundaries could be anticipated. Hazard boundaries for the other river valleys are based on mapped limits of past flows and the expected mitigative effect of the hydroelectric reservoirs in the Lewis River valley.

Potential Water Sources for Lahars at Mount St. Helens

If a large lahar were to occur at Mount St. Helens within the next few decades, the mechanism most likely to be responsible would be rapid melting of snow and ice in the crater or a sudden outbreak of Castle Lake. Either mechanism would produce a lahar only in the North Fork Toutle River (and downstream). Rainfall is seldom intense enough to directly produce lahars in the Cascades, and the flows produced by this mechanism tend to be fairly small. Likewise, any landslides occurring on the flanks of Mount St. Helens are likely to be relatively small, especially now that the volcano's height has been lowered by the 1980 eruption.

\section{Snow and lce at Mount St. Helens}

A large volume of snow and ice is presently accumulating in the Mount St. Helens crater, protected by the shade of the high, steep crater walls. This accumulation provides a growing potential water source for lahars in the North Fork Toutle River valley (Fig. 4). It is already mixed with rock debris eroded from the crater walls, and this debris would augment the formation of a lahar. It is

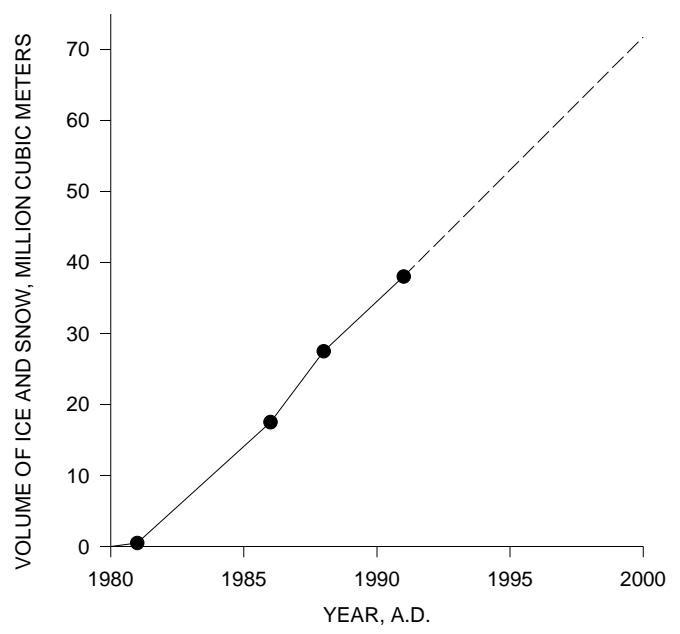

Figure 4. Volume of ice and snow in the Mount St. Helens crater. Measured data (dots) from H.H. Mills (written comm., 1994); dashed line, extrapolated. 
possible that a large eruption could melt most or all of this snow and ice in a matter of tens of minutes. A very small eruption in 1982 rapidly melted enough snow and ice in the crater to trigger a 4 million $\mathrm{m}^{3}$ (5.2 million $\mathrm{yd}^{3}$ ) flood that transformed into a lahar and flowed all the way to the Cowlitz River. At the present time (1995), about 53 million $\mathrm{m}^{3}$ (70 million $\mathrm{yd}^{3}$ ) of snow and ice has accumulated. If completely melted, this would produce about 38 million $\mathrm{m}^{3}\left(50\right.$ million $\left.\mathrm{yd}^{3}\right)$ of water. At the present rate of accumulation, the volume of snow and ice will double in about 15 years.

Permanent and seasonal snow and ice also blanket the outer flanks of Mount St. Helens. A sufficient volume exists there in winter or spring to produce flank lahars similar in magnitude to those of May 18, 1980, if another large eruption were to occur. Lahars formed on the outer flanks can be expected to be substantially smaller than flows generated in the crater.

\section{Lakes in Valleys Draining Mount St. Helens}

A number of natural and human-made lakes exist close to the volcano in the North Fork Toutle and Lewis River valleys. The uppermost lake in the Lewis River valley, Swift Reservoir, receives drainage from the volcano via Swift Creek, Pine Creek, and Muddy River. In 1980, lahars descending these streams dumped about 14 million $\mathrm{m}^{3}$ (18 million $\mathrm{yd}^{3}$ ) of sediment and water into the lake, abruptly raising the lake level $0.85 \mathrm{~m}(2.8 \mathrm{ft})$. Because the operators of the reservoir, Pacific Power and Light, lowered the lake level about 18 $\mathrm{m}(23 \mathrm{ft})$ below normal in anticipation of possible lahars, the small lake-level rise and the $0.4 \mathrm{~m} \mathrm{(1.3}$ $\mathrm{ft})$ accompanying wave posed no threat to the dam. It is assumed that (1) future lahars reaching Swift Reservoir would not be appreciably larger than those of May 18, 1980, and (2) dam operators would again take precautionary steps to lower lake level if Mount St. Helens were to show signs of imminent eruption. Therefore, Swift Reservoir and the downstream lakes (Yale Lake and Lake Merwin) are not considered to be at risk from lahars.

Three natural lakes in the North Fork Toutle River, formed by natural debris dams during the 1980 eruption, have required modifications to their outlets in order to prevent catastrophic outbreaks. The U.S. Army Corps of Engineers provided (1) a tunnel outlet to Spirit Lake, (2) a bedrock spillway channel at Coldwater Lake, and (3) a reinforced spillway channel at Castle Lake to hold the levels of these lakes constant and to prevent them from overtopping their erodible natural dams. A recent study (Roeloffs, 1994), however, has verified earlier conclusions that the natural dam at Castle Lake is potentially susceptible to modes of failure other than overtopping and, under certain conditions, is only marginally stable. Castle Lake contains about 23 million $\mathrm{m}^{3}$ (30 million $\left.\mathrm{yd}^{3}\right)$ of water and would produce a large lahar if the blockage were to fail. We assume that an outbreak of Castle Lake is a potential hazard, and the inundation levels of a numerically modeled lahar with an initial magnitude of 37,400 $\mathrm{m}^{3} / \mathrm{s}$ (1.32 million cfs) were used to produce the Zone-3 hazard boundaries in the North Fork Toutle, main Toutle, and Cowlitz Rivers. This model lahar (for which we conservatively assumed the SRS "full" condition and a bulking factor of 3.3) has an intermediate magnitude within the range of possible lahars modeled by MacArthur and others (1990b) for a potential outbreak of Castle Lake. Channel cross sections from a previous modeling study (Laenen and Orzol, 1987) were used to translate flow magnitude at different points into approximate lahar-inundation levels.

\section{Effect of the SRS Sediment Dam on Downvalley Lahar Hazard}

The U.S. Army Corps of Engineers constructed a sediment dam, called the Sediment Retention Structure or SRS, in the North Fork Toutle River to trap the large volumes of sediment washing down the river from the fresh volcanic deposits near Mount St. Helens. The SRS is located just upstream of the Green River confluence and was completed in 1989. The 56-m-(184-ft-) high dam has already lost more than half of its original freeboard due to infilling by sediment and is expected to be completely full (to the spillway crest) by about 2005 . The remaining capacity and the dam's ability to trap a lahar decrease every year. The reinforced spillway was designed to safely pass a flood discharge of $6,460 \mathrm{~m}^{3} / \mathrm{s}(228,000$ cfs).

The numerical modeling by MacArthur and others, (1990b) indicates that a range of lahar 
magnitudes is possible, depending on assumptions made about the level of Castle Lake, the mode of breaching of the debris dam, the amount of sediment picked up by the flood to form a lahar (bulking factor), and the level of sediment fill behind the SRS. Given that Castle Lake is now fixed at its "full" level, flow through the SRS spillway could vary from $1,350 \mathrm{~m}^{3} / \mathrm{s}(47,600 \mathrm{cfs})$ to $6,710 \mathrm{~m}^{3} / \mathrm{s}(237,000 \mathrm{cfs})$, depending on whether the reservoir was partly full of sediment (1990 existing condition) or completely full and depending on whether lahar volume increased 2.5, 3.3 , or 4.5 times due to incorporation of eroded sediment. At the SRS-outflow discharge considered most likely by the Corps of Engineers $\left(2,980 \mathrm{~m}^{3} / \mathrm{s}[105,200 \mathrm{cfs}]\right)$, the lahar reaching the Cowlitz River would be approximately equivalent to a 100-year flood. Such a lahar would be fully contained within the channel at both Kelso-Longview and at Castle Rock. At the high end of the range, flooding would occur all along the Cowlitz River both downstream and slightly upstream of the Toutle River confluence. The modeled lahar chosen to define the Zone 3 hazard boundaries (bulking factor 3.3; SRS "full") would be contained within channel at Kelso-Longview but not at Castle Rock nor in parts of the Toutle River valley between the SRS and the Cowlitz River.

The present water-equivalent volume in the Mount St. Helens crater is 65 percent larger than the volume of lake water in Castle Lake, but it is also about $10 \mathrm{~km}$ farther upstream. We assume that the additional distance would attenuate lahar peak discharge coming from the crater to roughly the scale of a lahar that would be produced by an outbreak of Castle Lake. Therefore, the potential Castle Lake lahar is used to delineate lahar-hazard zones on the map. However, the volume of snow and ice in the crater is steadily growing and steadily increasing the possibility of creating a flood too large to be contained by the SRS. At the same time, the SRS is steadily being filled in with sediment and decreasing in its ability to trap lahars. For example, in about 15 years the crater could have approximately twice as much snow and ice as now, and an eruption then could potentially produce a lahar roughly 100 percent larger than the zone-3 model lahar. Earlier modeling by MacArthur and others (1990a) showed that a lahar 84 percent larger than the zone- 3 model lahar could be expected to overtop the SRS by about $3 \mathrm{~m}(10 \mathrm{ft})$ if the reservoir were full of sediment. Overtopping of the $\mathrm{N}-1$ sediment dam by a lahar in 1982 heavily damaged and breached that structure in two places. Because of the many uncertainties involved in trying to quantify these predictions, such as the continued rate of infilling of crater ice and snow, the melt rate of ice and snow during an eruption, the expected bulking factor for a lahar coming from the crater, and the size and type of the next eruption, it is impossible to predict exactly when a potential lahar might be large enough to overtop the SRS. However, a lahar of such a magnitude is possible sometime within the next few decades. Overtopping (and possible breaching) of the SRS could result in significantly greater lahar flooding in the Toutle and Cowlitz Rivers than is postulated on the accompanying hazard map.

\section{MONITORING AND WARNINGS}

Volcanic activity at Mount St. Helens is carefully monitored by the U.S. Geological Survey and the University of Washington. Some kinds of events, such as crater-wall avalanches or steam-driven explosions from the dome have occurred without warning in the past and may do so again. However, our experience since early 1980 at Mount St. Helens and elsewhere indicates that the monitoring is sufficient for us to detect the ascent of fresh magma that must take place before another large eruption. As in the past, interpretation of phenomena related to magma ascent will enable us to provide warnings and updated assessments of hazards.

Lahar and flood hazards are monitored by the U.S. Geological Survey and the National Weather Service; the latter agency has responsibility for providing warnings of floods, including lahars. Currently monitoring includes: (1) lake-level gages on Castle, Coldwater, and Spirit Lakes, (3) sensors to measure movement on the Castle Lake debris dam, (3) flow-vibration sensors in the North Fork Toutle River valley to detect passage of lahars or floods, and (4) streamflow gages in the North Fork, South Fork, and main channel of the Toutle River and in the Muddy River. 


\section{REFERENCES CITED AND SUGGESTED READING}

Blong, R.J., 1984, Volcanic hazards-a sourcebook on the effects of eruptions: Academic Press, 424 p.

Carey, S., Gardner, J., and Sigurdsson, H., 1989, Intensity and magnitude of post-glacial plinian eruptions at Mount St. Helens [abstract], in Continental Magmatism Abstracts: New Mexico Bureau of Mines and Mineral Resources Bulletin 131, p. 43.

Crandell, D.R., and Hoblitt, R.P., 1986, Lateral blasts at Mount St. Helens and hazard zonation: Bulletin of Volcanology, vol. 48, no. 1, p. 27-37.

Crandell, D.R., and Mullineaux, D.R., 1978, Potential hazards from future eruptions of Mount St. Helens volcano, Washington: U.S. Geological Survey Bulletin 1383-C, 26 p.

Hoblitt, R.P., Miller, C.D., and Scott, W.E., 1987, Volcanic hazards with regard to siting nuclear-power plants in the Pacific Northwest: U.S. Geological Survey Open-File Report 87-297, 196 p.

Laenen, Antonius, and Orzol, L.L., 1987, Flood hazards along the Toutle and Cowlitz Rivers, Washington, from a hypothetical failure of Castle Lake blockage: U.S. Geological Survey Water-Resources Investigations Report 87-4055, 29 p.

Lipman, P.W., and Mullineaux, D.R., 1981, editors, The 1980 eruptions of Mount St. Helens, Washington: U.S. Geological Survey Professional Paper 1250, 844 p.

MacArthur, Robert C., Hamilton, Douglas L., and Mason, Ronald C., 1990a, Numerical simulation of mudflows from the hypothetical failure of a debris blockage lake below Mount St. Helens, WA, in French, R.H., ed., Hydraulics/hydrology of arid lands, Proceedings of the International Symposium at San Diego, CA, July 30-August 2, 1990: American Society of Civil Engineers, New York, p. 416-421.

MacArthur, Robert C., Brunner, Gary, and Hamilton, Douglas, 1990b, Numerical simulation of mudflows from hypothetical failures of the Castle Lake debris blockage near Mount St. Helens, WA: Final Project Report No. 90-05 (unpublished), U.S. Army Corps of Engineers Hydrologic Engineering Center, 609 Second St., Davis, CA 95616, $25 \mathrm{p}$.

Major, J.J., and Scott, K.M., 1988, Volcaniclastic sedimentation in the Lewis River valley, Mount St. Helens, Washington-processes, extent, and hazards: U.S. Geological Survey Bulletin 1383-D, 38 p.

Miller, C.D., Mullineaux, D.R., and Crandell, D.R., 1981, Hazards assessments at Mount St. Helens, in Lipman, P.W., and Mullineaux, D.R., editors, The 1980 eruptions of Mount St. Helens, Washington: U.S. Geological Survey Professional Paper 1250, p. 789-802.

Mullineaux, D.R., in press, Pre-1980 tephra-fall deposits erupted from Mount St. Helens, Washington: U.S. Geological Survey Professional Paper.

Pallister, J.S., Hoblitt, R.P., Crandell, D.R., and Mullineaux, D.R., 1992, Mount St. Helens a decade after the 1980 eruptions: magmatic models, chemical cycles, and a revised hazards assessment: Bulletin of Volcanology, vol. 54, no. 2, p. 126-146.

Pierson, T.C., 1985, Initiation and flow behavior of the 1980 Pine Creek and Muddy Creek lahars, Mount St. Helens, Washington: Geological Society of America Bulletin, v. 96, no. 8, p. 1056-1069.

Roeloffs, Evelyn A., 1994, An updated numerical simulation of the ground-water flow system for the Castle Lake debris dam, Mount St. Helens, Washington, and implications for dam stability against heave: U.S. Geological Survey Water-Resources Investigations Report 94-4075, 80 p.

Scott, K.M., 1988, Origins, behavior, and sedimentology of lahars and lahar-runout flows in the Toutle-Cowlitz River system: U.S. Geological Survey Professional Paper 1447-A, 76 p.

Scott, W.E., 1989, Volcanic and related hazards, in Tilling, R.I., editor, Volcanic Hazards, American Geophysical Union Short Course in Geology, vol. 1, p. 9-23.

Yamaguchi, D.K., and Hoblitt, R.P., in press, Tree-ring dating of pre-1980 volcanic flowage deposits at Mount St. Helens, Washington: Geological Society of America Bulletin. 